\section{Prof. Ezzoura Errami - A Profile}

IUGS Councillor (2010-2014)

Prof. Errami is currently working as a full Professor in the Department of Geology at Chouaib Doukkali University in El Jadida, Morocco. She is the President of the African Association of Women in Geosciences "AAWG, www.aawg.org" (2008-2012) and was the Assistant General Secretary of the same association during 2004 to 2008. She is also IUGS Councillor (2008-2012). Prof. Errami graduated with a B.Sc. Degree in

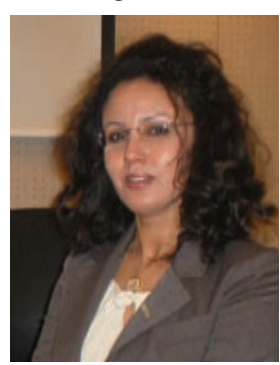
Geology from the Chouaib Doukkali University of El Jadida in 1989. She obtained postgraduate degree from the Cadi Ayyad University Marrakech "Diplôme des Etudes Supérieures" in 1993. She did her "Doctorat Es-Sciences" in 2001 as a collaboration between Chouaib Doukkali University (El Jadida, Morocco) and Ruprecht Karls Univesity (Heidelberg, Germany) in the field of petrology and structural geology using the Anisotropy of Magnetic Susceptibility (AMS). Her current major research interests are gender, geoheritage and geotourism, geoeducation, environmental economy and sustainable development. Prof. Errami continues to work in petrology, geochemistry, structural geology using AMS on magmatic rocks. Prof. Errami has received numerous scholarship and research grants (DAAD Scholarship, European Commission Fellowship "Tempus"...). In 2008, she obtained a certificate of the follow up and the validation of the training of trainers in environmental economy and the attestation of acquisition of the skills necessary to realize studies of expertise in environmental economy delivered by Ecosys Geneva et Sba Sustainable Business Associates (Suisserland) and Chouaib Doukkali University (El Jadida, Morocco). Prof. Errami has been part of many projects and also author and coauthor of many scientific papers, abstracts, reports and guidebooks. Prof. Errami encourages women to publish their scientific works by co-editing two special volumes related to women and geosciences including one in the Journal of African Earth Sciences entitled "Aspects of geological knowledge for sustainable development in Africa: Women in Africa Geoscience". As founding editor of an electronic journal entiled "Women and Geosciences News". Prof. Errami is a leader and member of executive committees of many professional international and national organizations. She is a member of the Organization for Women in Science for the Developing World (OWSD) and a life member of the GSAf. During 2009 Prof. Errami initiated the African Geoparks Network "AGN". She is chairing the First International Conference on African and Arabian geoparks entitled "Aspiring geoparks in Africa and the Arab world" to be held in Morocco from the $20^{\text {th }}$ to $28^{\text {th }}$ November 2011. She is also member of the organizing committee of the $6^{\text {th }}$ conference of the African Association of Women in Geosciences entitled "women and Geosciences for African Integration" which will be organized from the 23 to 27 April 2012 in Yaoundé (Cameroon). She is also co-organizing and co-moderating a roundtable on «Women in Geosciences » during the YES Network Congress to be held in 2012 in Brisbane (Australia). She is coconvening a session entitled « Role of women geoscientists in resource development» organized by AGID during the $34^{\text {th }}$ IGC in Brisbane, Australia.

Prof. Errami is the founder President of the Association "Civilizations without borders" whose main objective is the promotion of the dialogue of civilizations. She is also member of the bureau of the association of disadvantaged old persons of her city. 